p-ISSN: 2559-7639 | e-ISSN: 2668-0718 | DOI:10.18662/jsmi | Frequency: 1 issue per year with 1-2 possible supplementary issues

Covered in: CrossRef; RePEC; CEEOL; Google Scholar, ICI Journals Master List - Index Copernicus 2021, Volume 3, Issue 1, pages: 106-118 | https://doi.org/10.18662/jsmi/3.1/20

\section{Posthumanism and the}

\section{New Ethics of Medical}

\section{Practice-}

\section{Epidemiology as the}

New Deontological

\section{Paradigm}

\section{[Postumanul şi noua abordare în \\ practica medicală-Epidemiologia}

ca paradigmă deontologică]

\section{Timea VITAN ${ }^{1}$}

${ }^{1}$ Resident doctor, University of Medicine and Pharmacy "Carol Davila" Bucharest, Romania, jarcatimea@gmail.com
Abstract: In the context of the COVID19 pandemic, during last year all public attention has been focused on Medicine. Epidemiology is no longer just one medical specialty among many others, but became the main paradigm and the unique background of medical science. The individual pacient has turned into the collective pacient. Medical policies are not centered on the pacient anymore, but on its social group.

In this article I will try to show how the characteristics of medical practice changed since the pandemic began and which are the deontological implications of such changes. With a short introduction on the medical policies proposed by the WHO during the last decades, I wish to underline the recent history of medical practice and its obvious turning point occasioned by the pandemic. Once the new bioethical vantage points are set, I wonder to which extent posthumanist philosophy foresaw this new deontological paradigm. Having Rosi Braidotti's "The Posthuman" as my starting point, I maintain that medical doctors no longer practice on a bumanist background, but with a sort of commitment that goes beyond the individual. However, this is not an antibumansit pledge, because contemporary medical doctors still adhere to certain humanist principles.

As it so often happens, we will be left with even more questions. If the pacient is no longer the individual, but the group of individuals, which is the nature of a symptom and how should we decipher its meaning? How would a new medical science look like if we are to build it not on a buman but on a posthuman biology?

Keywords: epidemiology, deontology, COVID-19, posthumanism, bioethics.

How to cite: Vitan, T. (2021). Posthumanism and the New Ethics of Medical Practice-Epidemiology as the New Deontological Paradigm. Journal for Social Media Inquiry, 3(1), 106-118.

https://doi.org/10.18662/jsmi/3.1/20 


\section{Introducere}

\subsection{Clinicianul, între pacient şi societate}

Când pandemia de COVID-19 a izbucnit la începutul anului 2020, Planeta a intrat, în primul rând, într-o adevărată criză politică şi socială. Problema inițială a fost, într-adevăr, una de ordin medical (sau, mai exact, de ordin biologic_-infectarea pacientului zero cu noua formă de Coronavirus), iar efectele financiare ale pandemiei sunt încă în faţa noastră. Dar dacă omenirea a mai trecut prin epidemii, şi dacă crizele financiare au o oarecare ciclicitate, dimensiunile actuale ale populației umane, precum şi strânsele interconexiuni existente azi între oamenii de la diferite capete ale Planetei, sunt cu siguranță aspecte despre care istoria nu a mai vorbit până acum. Dacă o epidemie este nu o boală a individului, ci a grupului de indivizi, atunci anul 2020 a obligat omenirea să se confrunte cu acest tip de boală într-un context nemaiîntâlnit până acum-peste 7 milioane de indivizi care dispun de o tehnologie ce le permite să fie în permanenţă în contact unii cu alții. Deloc surprinzător, medicii clinicieni au fost primii care au simţit presiunea acestei crize. Un anumit aspect al experienței clinicianului pe timpul pandemiei ne va interesa în cele ce urmează: dilema de ordin moral, pe care mulţi practicieni au trăit-o şi, am putea spune, chiar manifestat-o, ridicată de întrebarea dacă angajamentul medicului este față de pacient, sau față de grupul social din care acesta provine? În contextul unei situații noi, despre care ştiinţa ne poate spune deocamdată prea puține, care este scopul actului medical, respectiv cum se poate rezolva scindarea lui între liberul arbitru al pacientului individual şi binele comun al populației din care acesta face parte? Mergând mai departe cu interogațiile de natură bioetică, vom încerca să vedem care a fost rolul filosofiei în această discuției şi, eventual, care ar putea fi liniile indicatoare sugerate de ea pe mai departe.

Spuneam mai sus că epidemiile sunt boli ale grupului de indivizi. Medicina este însă ştiința care studiază omul. Pentru a rezolva problemele etice trebuie deci să ne canalizăm puțin atenția asupra celor de natură epistemologică. Un posibil punct de plecare este noua teorie a subiectivităţii aşa cum a fost expusă de Rosi Braidotti în cartea sa Postumanul (Braidotti, 2016). Un lucru pe care pandemia de COVID-19 ni l-a demonstrat este că nu mai putem vorbi într-o paradigmă antropocentrică, nici măcar în medicină. Odată privit ca grup de indivizi, omul îşi pierde statutul special în cadrul viziunii despre lume, iar strânsa sa dependenţă de toţi ceilalţi actori sociali devine evidentă. Virusul nu mai este doar un celălalt, un obstacol pe care omenirea trebuie să îl depăşească, ci este o entitate de sine stătătoare, cu 
la fel de multă autoritate precum omul. Aşa cum pare să indice şi filosofia postumanului, dacă vrem să continuăm să înțelegem, trebuie să-l integrăm pe acest celălalt, să trecem dincolo de noi înşine, să privim viaţa-în orice formă a ei-ca pe un mare organism unic. Şi totuşi, care este linia de start a medicului în această discuție?

\subsection{Jurământul lui Hippocrate şi codurile deontologice}

Timp de aproape 2300 de ani toate principiile eticii medicale au avut la bază Jurământul lui Hippocrate. Menționat pentru prima dată în jurul anului 275 î. Hr. de către medicul grec Hippocrates din Kos, în forma lui actuală, adoptată de Asociația Medicală Mondială în cadrul Declaraţiei de la Geneva în 1975, el sună în felul următor:

„Odată admis printre membrii profesiunii de medic:

Mă angajez solemn să-mi consacru viața în slujba umanității;

- Voi păstra profesorilor mei respectul şi recunoştința care le sunt datorate;

- Voi exercita profesiunea cu conştiinţă şi demnitate;

- Sănătatea pacienților va fi pentru mine obligație sacră;

- Voi păstra secretele încredinţate de pacienți chiar şi după decesul acestora;

- Voi menține prin toate mijloacele onoarea şi nobila tradiție a profesiunii de medic;

- Colegii mei vor fi fraţii mei;

- Nu voi îngădui să se interpună între datoria mea şi pacient considerații de naționalitate, rasă, religie, partid sau stare socială;

- Voi păstra respectul deplin pentru viața umană de la începuturile sale chiar sub ameninţare şi nu voi utiliza cunoştințele mele medicale contrar legilor umanităţii.

Fac acest jurământ în mod solemn, liber, pe onoare.” (Ioniţă, 2016).

Trasând câteva reguli foarte generale, şi de altfel atât de cunoscute încât ne par în ziua de azi banale, jurământul are totuşi două puncte ce apar problematice în contextul unei epidemii-principiul confidențialității, respectiv cel al nondiscriminării. Primul devine problematic pentru că epidemia este, prin definiție, o problemă de sănătate publică, iar principiul nondiscriminării ridică pe de o parte problema liberului arbitru al pacientului, iar pe de altă parte problema naturii cunoaşterii medicale, cunoaştere care, cel puțin în primele luni ale pandemiei, s-a dovedit a fi mai degrabă una speculativă, şi nu o certitudine-aşa încât atitudinea faţă de manifestările şi măsurile luate în pandemie a fost, inevitabil, dependentă de credinţele şi adeziunile personale ale fiecăruia, indiferent că vorbim despre medici sau 
pacienți. Încă un aspect important legat de Jurământul lui Hippocrate şi relevant pentru discuția de față este caracterul lui secular, umanist. Fără să facă trimitere la autorități metafizice şi fără să considere omul ca simplu element al mediului din care provine, e lesne de înţeles de ce acest jurământ a existat şi a evoluat de-a lungul timpului într-o simbioză perfectă cu principalele curente filozofice, politice şi culturale ale Occidentului (Târcoveanu et al., 2013).

Datorită complexității lumii contemporane acest jurământ este insuficient pentru a asigura o practică medicală corectă. Aş îndrăzni să spun că Jurământul lui Hippocrate a devenit în mod definitiv lacunar pentru deontologia medicală odată cu stabilirea epidemiologiei ca domeniu clinic şi de cercetare, bineînțeles în cadrul mai larg al ştiinței medicale. Totuşi, chiar şi înaintea pandemiei, clinicianul avea la dispoziție coduri deontologice pentru îndreptarea şi cizelarea actului medical. Dintre acestea mai reprezentative ni s-au părut Codul Deontologic al Colegiului Medicilor din România, respectiv Code of Professional Conduct for Case Managers folosit în Statele Unite ale Americii. Începând cu codul valabil în țara noastră, redăm mai jos acele articole care ni s-au părut mai relevante în acest context:

„Art. 9 Medicul are independență profesională absolută, libertatea absolută a prescripțiilor şi actelor medicale pe care le consideră necesare, în limitele competenței sale, şi este răspunzător pentru acestea. În cazul limitării prin constrângeri administrative şi/sau economice a independenței sale, medicul nu este răspunzător.

Art. 14 Secretul profesional este obligatoriu, cu excepția situațiilor prevăzute de lege.

Art. 16.-Secretul profesional trebuie păstrat şi față de aparținători, dacă pacientul nu doreşte altfel.

Art. 17.-Secretul profesional trebuie păstrat faţă de colegi, cadre sanitare şi instituțiile medicale care nu sunt implicate în actul medical al pacientului în cauză.

Art. 39.-Medicul nu poate face reclamă unor medicamente sau bunuri medicale de consum

Art. 49.-Medicul trebuie să respecte dreptul persoanei în privința opțiunii libere asupra medicului său curant şi chiar să faciliteze această posibilitate.

Art. 70.-Medicul are obligația morală de a aduce la cunoştință organelor competente orice situație de care află şi care reprezintă un pericol pentru sănătatea publică. 
Art. 91.-În cercetarea pe subiecți umani, binele individului primează asupra binelui societății în general şi al ştiinței."(Codul Deontologic al Colegiului Medicilor din România, 2016)

Observăm că în afara Art. 70, care se referă la sănătatea publică, toate celelalte articole de mai sus au fost, într-o mai mare sau mai mică măsură, încălcate în practica clinică din timpul pandemiei: medicul nu a putut fi independent în acţiunile sale şi răspunzător pentru acestea pentru simplul fapt că pandemia este ceva atât de nou încât clinicianul nu are informația necesară; secretul profesional faţă de pacient nu are niciun loc în probleme de sănătate publică; vaccinul este un bun medical de consum; carantina este o măsură de limitare a libertăţii; rapida apariție e vaccinului împotriva COVID-19 a avut ca motivație principală efectele nefaste ale pandemiei, mai degrabă decât eficiența terapeutică a noilor tehnologii folosite. Toate aceste fapte indică nevoia acută de a reconsidera paradigmele bioeticii şi în special poziția subiectivității clinicianului în ziua de azi.

În legătură cu principalele principii deontologice avute în vedere în spațiul anglo-saxon, ele sunt patru la număr şi pot fi rezumate astfel:

- Principiul autonomiei - orice pacient are libertate absolută în ceea ce priveşte sănătatea personală, tratamentele, investigațiile şi intervențiile medicale la care este supus (Drumwright, 2015, pp. 431-58).

- Principiul binefacerii - practicianul oferă îngrijire în interesul pacientului. Acest principiu ridică problema determinărilor subiective şi obiective, a raportului între avantajele şi dezavantajele unei intervenţii. $\mathrm{O}$ decizie binefăcătoare este obiectivă dacă ea este aceeaşi indiferent cine e agentul decizional (Drumwright, 2015, pp. 431-58).

- Principiul primum non nocere - actul medical nu trebuie sub nicio formă să dăuneze (Drumwright, 2015, pp. 431-58).

- Principiul justiţiei - dacă principiile etice hippocratice erau strict legate de relaţia individuală dintre clinician şi pacient, etica medicală în ziua de azi trebuie extinsă dincolo de individ, la nivel instituțional şi social. Principiul justiţiei are două aspecte: cel distributiv şi cel comparativ. Primul se referă la distribuirea echitabilă a resurselor, cel de-al doilea priveşte tratamentul individualizat în funcție de particularitățile pacientului. După cum vedem, aici este punctul principal de separare între vechile valori şi realitatea actului medical contemporan (Drumwright, 2015, pp. 431-58).

\section{Schimbarea de paradigmă}

\subsection{Epidemiologia şi tandemul său cu filosofia}


Dacă umanismul, înțeles aici ca acel curent filosofic care pune în centrul său ființa umană, şi-a găsit apogeul undeva pe la jumătatea secolului XIX şi a început să fie contestat, aşa cum arată Braidotti (2016, p. 27), în special după Cel De-al Doilea Război Mondial, ne-am întrebat când au început medicii să vadă omul nu doar ca un subiect izolat, ci ca parte dintrun organism mai larg. La fel ca în filosofie, istoria acestei ramuri începe cu termenii din Grecia Antică-endemie (însemnând boală ce apare doar întrun anumit spaţiu) şi epidemie (adică boală ce apare doar într-o anumită perioadă de timp). Cum spuneam şi la începutul articolului, pandemia (o boală care să fie peste tot într-o perioadă dată) cu care ne confruntăm este, fără îndoială, primul fenomen din genul său. Epidemiile de ciumă şi holeră din epoca modernă au făcut deja subiectul multor cărți şi tratate, unele dintre ele căutând explicații şi soluții de natură teologică, altele având o viziune empirică şi propunând rezolvări care încă sunt de actualitate (igiena corespunzătoare, carantinarea şi izolarea, etc.). Indrăznim să vorbim despre un tandem între epidemiologie şi filosofie pentru că, încă din secolul XVI, când Quionto Tiberio Angelerio propunea cele 57 de reguli de igienă şi carantinare (Gorvett, 2021), a putut fi observată importanța curentului filosofic prevalent la acea dată-regulile lui Angelerio au fost puternic contestate pentru că boala masei de oameni era considerată o pedeapsă venită de la Dumnezeu, astfel încât ciuma s-a extins, marcând parcursul istoric al erelor următoare. În secolul XIX, epidemia de holeră a ocazionat apariția epidemiologiei ca ştiinţă, John Snow fiind cel care a trasat principiile şi metodologia acestui domeniu (Brundtland, 1998).

Dar până în acest punct vorbim doar despre corelații istorice între diverse fenomene biologice şi curentele cultural-filosofice contemporane lor. Epidemiologia ca paradigmă ştiințifică pentru o deontologie medicală îşi are rădăcinile în momentul înființării primelor organizații medicale internaţionale, deoarece acestea au luat naştere din motive financiare şi politice, adică au încercat să normeze tocmai acele aspecte ale actului medical care privesc populaţia şi nu individul. Din acest punct de vedere, primul moment important a fost data de 23 iulie 1851, când la Paris a avut loc prima Conferinţă Sanitară Internatională, conferință ce viza în primul rând epidemia de holeră şi stabilirea unor standarde internaţionale pentru carantinarea navelor în principalele porturi ale Europei. Apoi, prin semnarea Acordului de la Roma în 1907, a fost înființat Oficiul Internațional de Igienă Publică. Conform istoriei oficiale a Organizației Mondiale a Sănătății, principalul scop al acestui oficiu era de a oferi statelor membre informații de sănătate publică, accentul fiind pus pe bolile transmisibile (holeră, ciumă, febră galbenă) şi pe modalitățile de a le combate. Un fapt demn de luat în seamă este pregătirea 
profesională a membrilor acestui oficiu, doar parte din ei tehnocrați, majoritatea fiind diplomați sau politicieni. Istoria Organizației Mondiale a Sănătătii arată că dorința de colaborare internațională eficientă în chestiuni de sănătate publică a precedat cu mulți ani cunoaşterea ştiințifică necesară unei asemenea colaborări. Abia după sfârş̧itul secolului XIX, în principal prin avântul în microbiologie, ştiinţa a putut spera să furnizeze o bază cât de cât stabilă pentru aceste politici publice. Organizația Mondială a Sănătăţii, în forma care ne este cunoscută azi, a fost înfiinţată în 1946, reuşind în perioada de după Al Doilea Război Mondial să îşi asigure rolul de portavoce a politicilor şi practicilor medicale din întreaga lume (World Health Organization, 1958).

\subsection{Constituţia OMS şi evitarea antiumanismului}

Doar pentru că nu implică o cauzație, corelația nu trebuie ignorată ca posibilă sursă de informaţii. Aşa încât trebuie să observăm înşiruirea Jurământul lui Hippocrate - Codurile Deontologice - Constituția Organizației Mondiale a Sănătăţii, ca documente ce au fost, pe rând, stindardele deontologice ale clinicianului, şi care îşi găsesc un răsunet în parcusul istoric al umanismului. Dacă nu pentru altceva decât de dragul consecvenței, redăm mai jos punctele Constituției:

- „Sănătatea este definită ca starea de bine fizic, psihic şi social, nu doar ca absența bolii sau infirmității.

- Accesul la cele mai înalte standarde de sănătate posibile este unul dintre drepturile fundamentale ale omului, fără distincție de rasă, religie, orientare politică, situație socială sau economică.

- Sănătatea tuturor popoarelor este fundamentală pentru pace şi securitate, fiind dependentă de întreaga cooperare a indivizilor şi statelor.

- Succesul fiecărui stat în promovarea şi protejarea sănătăţii este valoroasă pentru toate celelalte.

- Dezvoltarea inegală dintre diferitele țări în promovarea sănătăţii şi controlul bolilor, în special a celor transmisibile, este un real pericol.

- Dezvoltarea sănătoasă a copilului are o importanță capitală; abilitatea de a trăi armonios într-un mediu ce se află într-o continuă schimbare e esențială pentru o asemenea dezvoltare.

- Extinderea înspre toate popoarele a beneficiilor cunoaşterii medicale, psihologice sau asociată acestora este esențială pentru obținerea sănătățiii.

- Opinia informată şi cooperarea activă din partea publicului sunt de cea mai mare importanță pentru îmbunătățirea sănătății populației. 
- Guvernele sunt responsabile de sănătatea popoarelor lor, responsabilitate ce poate fi îndeplinită doar prin măsuri de sănătate publică şi sociale adecrate." (WHO, 2020.)

Vedem că însăşi paradigma în care au fost formulate valorile şi principiile ce stau la baza Constituției este complet diferită de viziunea despre lume a medicului hippocratic. Ori, de la începutul pandemiei şi până azi, informațiile, indicațiile şi sugestiile considerate valide în practica clinică au fost cele diseminate de Organizația Mondială a Sănătăţii. Cadrele medicale active, din întreaga lume, au prioritizat în ultimele 18 luni directivele venite din partea acestei organizaţii. Considerăm, deci, că nu e deplasat să spunem că o nouă deontologie trebuie să pornească de la această Constituție.

Din textul redat mai sus reiese că aceste noi premise nu s-ar încadra la ceea ce Braidotti ar numi 'antiumanism' (Braidotti, 2016). Ele nu propun găsirea Supraomului, şi nici nu contestă, de exemplu, validitatea drepturilor omului (cum ar face Nietzsche sau Marx), respectă în circumstanțele relevante principiul autonomiei (chestionat de Heidegger) şi evită un determinism absolut. Prin această atitudine deschisă, noua deontologie medicală ar trebui să integreze şi să depăşească atât valorile umanist antropocentrice cât şi contravalorile propuse de antiumanişti, dezvoltându-se într-un cadru mai larg, mai atotcuprinzător-cel al postumanismului. Care este procesul subiectiv şi noul angajament filosofic ce trebuie făcut pentru a dispune de instrumentele conceptuale necesare unei noi deontologii?

\subsection{Noile probleme etice-insuficiența utilitarismului}

E posibil ca la prima vedere problemele deontologice apărute odată cu trecerea de la pacientul individual la grupul de indivizi, să pară rezolvabile prin simplul apel la o etică utilitaristă. Dar utilitarismul presupune cunoaşterea unui bine comun (Mill, 2014). Ori, aşa cum menţionam mai sus, pandemia este un fenomen social şi politic complet nou, care aruncă ființa umană în mijlocul unei realităţi biologice ce nu mai permite o viziune antropocentrică. Omul este, în anul 2021, în mod evident subjugat celorlalți actori sociali, de aşa natură încât cel mai mare bine-subînțeles într-o etică utilitaristă—rămâne, deocamdată, de descoperit. Astăzi, nu putem spune doar că sănătatea grupului e mai presus decât sănătatea individului, trebuie luate în considerare şi aspectele non-medicale ale actului medical-ne putem gândi la partea financiară, materială sau chiar de opinie publică. Mai mult, ne putem întreba, cel mai mare bine, este cel mai mare bine pentru cine?

În plus, clinicianul care îşi ridică probleme etice trebuie, în ziua de azi, să treacă printr-un proces de defamiliarizare, sau mai exact, cum ar spune 
Braidotti, de dez-identificare (Braidotti, 2016, p. 75) cu angajamentul hippocratic. De fapt, în ochii clinicianului, pacientul nu mai este un individ uman tratat în limitele propriei sale bunăstări, ci e evaluat ca un element dintr-o mulțime de pacienți, binele acestora fiind de fapt scopul final al clinicianului. Ori, pentru a face asta, o discuție doar în cadrul unei etici utilitariste nu mai este suficientă, tocmai pentru că etica utilitaristă nu vorbeşte despre acest proces de defamiliarizare-nu cercetează schimbarea în percepția asupra lumii pe care clinicianului, ca subiect, trebuie să o suporte.

\subsection{Epidemiologia şi filosofia postumanului}

Se spune că nu există boli, există doar pacienți. Dacă această afirmație e una adevărată, putem spune că nu există epidemii, există doar țări în stare de criză. Aşa cum doi oameni diferiți vor reacţiona diferit la un anume medicament, sau la un anume agent patogen, fiecare în funcție de statusul său fiziologic, de vârstă, sex, ş.a.m.d., două țări diferite vor reacționa diferit la aceeaşi epidemie, în funcție de caracteristicile fiecăreia-media de vârstă, disciplina culturală, nivelul economic etc. Dar atunci când trecem de studiul unei specii la studiul unui gen, caracteristicile obiectului îşi schimbă natura-vârsta unui individ şi media de vârstă a unei populații nu sunt două proprietăți la fel de uşor măsurabile şi obiectivabile, statistica nu e algebră. Dacă în evaluarea şi tratarea unui subiect uman relaţiile de cauzalitate între parametrii săi hemodinamici şi simptom este una destul de clară şi liniară, lucrurile nu sunt la fel de simple atunci când pacientul este o întreagă populație. Să luăm un exemplu concret din pandemia de COVID-19-nu putem stabili cu exactitate dacă media de vârstă a populației sau nivelul de încredere pe care cetățenii îl acordă guvernului este mai relevant pentru depăşirea unei crize medicale. Epifenomenele culturale se întrepătrund cu fenomenele biologice, schimbând nivelul de analiză pe care trebuie să ne situăm. Aici, filosofia postumanului ne-ar putea oferi un intrument conceptual folositor: ştergerea, sau cel puțin estomparea, diferenței naturăcultură. În epidemiologie subiectivitatea trece de limitele sale biologice şi ajunge pe un tărâm în care expertiza tehnic-medicală a vindecătorului nu mai este suficientă. Epidemiologul se uită la oameni din aceeaşi perspectivă din care microbiologul se uită la bacterii, şi nu din perspectiva hippocratică a clinicianului ce are în faţă un pacient, motiv pentru care el trebuie să îşi cizeleze şi alte abilităţi de relaţionare cu obiectul de tratat pe lângă cele necesare tratării unui subiect uman. Când privim umanitatea ca grup de indivizi, comportamentul şi fenomenele biologice ne amintesc de un grup de indivizi din orice altă specie, aşa încât valorile promovate de postumanism- 
precum empatia, toleranța, poziția nonprivilegiată a omului-devin abilități indispensabile clinicianului.

Vorbind despre noua perspectivă impusă de discursul privitor la schimbările climatice, Braidotti îl citează pe Chakrabarty şi spune: ,aceste schimbări ale reperelor de bază afectează conținutul cercetării istorice prin distrugerea distincţiei artificiale, dar lăudate de-a lungul timpului, între istoriile naturale şi cele umane" (Chakrabarty, 2009, cit. in Braidotti, 2016). "Deşi Chakrabarty nu ia calea postantropocentrismului, ajunge la aceeaşi concluzie ca şi mine: problema perspectivelor centrate pe planetă şi pe schimbarea poziției oamenilor de la simpli agenți biologici la agenți geologici solicită reconfigurări atât ale subiectivității, cât şi ale comunității”" (Braidotti, 2016, p. 113). Aş îndrăzni să o parafrazez puțin la rându-mi pe Braidotti, spunând că problema perspectivelor medicale centrate pe populație şi pe schimbarea poziției pacientului, de la individ la vector de transmitere a bolii, solicită acelaşi tip de reconfigurări ale subiectivităţii, cât şi ale comunităţii, în cazul explicit al discuției mele fiind, bineînțeles, vorba despre angajamentul personal al clinicianului, respectiv despre codurile deontologice acceptate pe scară largă. Ori, realitatea medicală din ultimele decade ne-a demonstrat că această reconfigurare trebuie să țină seama de preceptele epidemiologice, să stabilească norme şi coduri deontologice adaptate globalizării şi nivelului de dezvoltare tehnologică pe care ne situăm. Probabil din acest motiv este atât de controversată problema pandemiei. In 2021 un medic adaptat actualelor curente bioetice (ne referim aici la această nouă deontologie care se conturează prin directivele Organizației Mondiale a Sănătăţii şi prin politicile de sănătate publică a diferitelor state) are un angajament cu valențe postumaniste faţă de pacient, căci pacientul său nu mai este subiectul uman, ci grupul şi mediul din care acesta face parte. Aşa ajungem la ceea ce Braidotti numeşte affirmative ethics (Braidotti, 2017). Depăşind dialectica hegeliană, cu toate opozițiile şi clarele ei delimitări, Braidotti propune o viziune spinozist monistă. Ce se înseamnă asta? Înseamnă în primul rând o deschidere pentru depăşirea sinelui, a individualităţii, şi o aruncare în lume, dincolo de individ — adică, dincolo de subiectul antropologic, dincolo de Om ca centru al gândiri. Ori, aşa cum am arătat mai sus, epidemiologia cere de la medicul clinician tocmai acest tip de angajament.

Există totuşi şi un punct de divergenţă între epidemiologie, în calitate de demers medical, şi filosofia postumanistă: viaţa în totalitatea sa privită ca zoè. În timp ce Braidotti propune o înglobare a tuturor formelor de viaţă, ca elemente echivalente, în acest concept de zoé (Braidotti, 2011), medicina mai presupune încă o opoziţie şi o luptă între macroorganisme şi microorganisme. Chiar şi aici discuția poate fi nuanțată dacă ne gândim la 
atitudinea clinicienilor față de bacterii-considerate pentru mult timp doar ca agenți patogeni, ştiința medicală a înțeles în ziua de azi importanţa lor pentru sănătatea individului şi are în vedere simbioza existentă, de exemplu, între Homo sapiens şi Bifidobacterium animalis. Totuşi, să nu uităm că eforturile medicilor în timpul pandemiei au fost direcționate spre a învinge un virusconsiderat şi el, o formă de viaţă, deci medicina continuă să fie un domeniu în care diferențele dintre noi şi ceilalți sunt indispensabile, oricât de mult am lărgi conceptual câmpul termenilor. Dacă va veni un moment în care filosofia postumanistă să constituie principalul fundament filosofic al actului medical, drumul până acolo este unul lung şi anevoios, în primul rând pentru că postumanismul însuşi mai are de clarificat unele aspecte proprii.

\section{Concluzii}

$\mathrm{Nu}$ este exclus ca starea de excepție pe care am experimentat-o în pandemie să devină o caracteristică permanentă a unei lumi noi. Țări precum Thailanda, Singapore sau Japonia, care au fost puternic afectate de alte epidemii, precum cea de SARS-Cov-1 sau de H5N1 (gripa aviară), au integrat unele practici de igienă, considerate până atunci excepţii (ca de exemplu purtarea măştii la metrou), în normalitatea vieții cotidiene. Dependența de tehnologie, socializarea în mediul digital, contopirea locului de muncă cu locul de acasă, sunt doar câteva dintre aspectele ce probabil nu au să dispară după sfârrşitul pandemiei. Lumea post-pandemie e o lume nouă, o lume care avea să vină. Această venire fiind ocazionată de un eveniment medical, domeniul sănătății este printre primele care trebuie să îşi reconsidere şi să îşi reconstruiască paradigmele, să stabilească noi norme şi să seteze un alt cadru conceptual prin care să poată da randament în această lume nouă. Vechile principii bioetice şi codurile deontologice încetăţenite până acum se dovedesc inutile clinicianului pentru că au la bază informații ştiințifice şi angajamente filosofice care au fost depăşite de realitatea acestei noi lumi. Dacă ştiința încearcă să se adapteze acestor noi condiții, la fel trebuie să facă şi filosofia. De această dată nu virtutea concurenței dintre ele, ci pentru că doar împreună mai pot spera să ne ofere instrumentele de care avem nevoie pentru a merge mai departe.

Ramura medicală care s-a făcut cea mai remarcată şi s-a dovedit cea mai relevantă în ultimul an şi jumătate a fost epidemiologia. Din acest motiv, regândirea normelor deontologice pornind de la perspectiva acestei ştiinţe, ni s-a părut un demers firesc. O deontologie epidemiologică ar trebui să fie adaptată populației actuale şi condițiilor de viață existente: să aibă în vedere faptul că medicul nu mai are o datorie doar față de pacient, ci şi față de restul societății; să țină cont nu doar de parametrii hemodinamici ai unui organism, 
ci şi de caracteristicile culturale ale acestuia; să accepte faptul că biologia nu pune omul pe un piedestal, ci mai degrabă îl coboară de acolo, şi să se raporteze la ființa umană ca element egal cu oricare alt element viu. Toate acestea presupun în primul rând un travaliu deconstructiv, o contestare radicală şi o nouă încercare de gândire a lumii.

Născută în urma eforturilor antiumaniste şi deconstructiviste de la începutul secolului trecut, filosofia postumanului, care a luat amploare odată cu noul mileniu, ne-a atras atenția ca posibilă sursă de indicații şi repere pentru reorientare. Unele dintre temele şi motivele propuse de aceasta, precum anularea barierelor dintre natură şi cultură, dezidentificarea cu subiectul sau ieşirea din paradigma antropocentrică, se dovedesc utile în procesul de reconstrucție al viitoarei deontologii medicale. Dilema formulată la început şi-a găsit o posibilă rezolvare în anularea dihotomiei prin intermediul monismului spinozist propus de Rosi Braidotti. Etica fiind locul în care practica şi teoria se întâlnesc pentru a rezolva problemele comune, acest articol poate fi considerat invitaţia venită din partea practicii către teorie-practica ridică întrebări, teoria e datoare ca măcar să le discute.

\section{References}

Braidotti, R., (2011). Nomadic Theory. The Portable Rosi Braidotti. Columbia University Press.

Braidotti, R. (2016). Postumanul (O. Anemțtoaicei, Trans.). Hecate. (Original work published 2013)

Braidotti, R. (2017, January 20). On Affirmative Ethics [Video]. https://rosibraidotti.com/2019/11/21/on-affirmative-ethics/

Brundtland, G. H. (1998, October 28). Importance of Snow. UCLA Department of Epidemiology.http://www.ph.ucla.edu/epi/snow/importance.html

Colegiul Medicilor din România, (2016). Codul de deontologie medicală, publicat în 7 decembrie 2016, Monitorul Oficial 981.

https://www.smlugoj.ro/data files/content/personal-drepturiobligatii/files/cod-deontologie-medicala.pdf

Drumwright, M. (2015). Behavioral ethics and teaching ethical decision making. Decision Sciences Journal of Innovative Education, 13(3), 431-58. https://doi.org/10.1111/dsji.12071

Gorvett, Z. (2021, January 8). The 432-year-old manual on social distancing. BBC Future. https://www.bbc.com/future/article/20210107-the-432-year-oldmanual-on-social-distancing 
Posthumanism and the New Ethics of Medical Practice-Epidemiology... Timea VITAN

Ioniță, B. (2016, January 5). Jurământul lui Hippocrate şi lumea modernă. Radio România. Agenţia de presă. https://www.rador.ro/2016/01/05/juramantullui-hippocrate-si-lumea-moderna/

Mill, J. S., (2014). Utilitarismul (V. Mureşan, Trans.) ALL. (Original work published 1863)

Târcoveanu, E., Vasilescu, A., Epure, O., \& Dorobăț, D. (2013). Mai este actual jurământul lui Hippocrat?. Jurnalul de chirurgie, 9(3), 205-207. http://www.jurnaluldechirurgie.ro/jurnal/docs/jurnal313/art $\% 201 \% 2020$ $13 \% 20 \mathrm{nr} \% 203 . \mathrm{pdf}$

World Health Organization. (1958). The First Ten Years of the World Health Organization. bttps:// apps.who.int/iris/bitstream/handle/10665/37089/a38153 eng LR part 1.pdf? sequence $=14$

World Health Organization. (2020). Constitution. https://apps.who.int/gb/bd/pdf files/BD 49th-en.pdf 